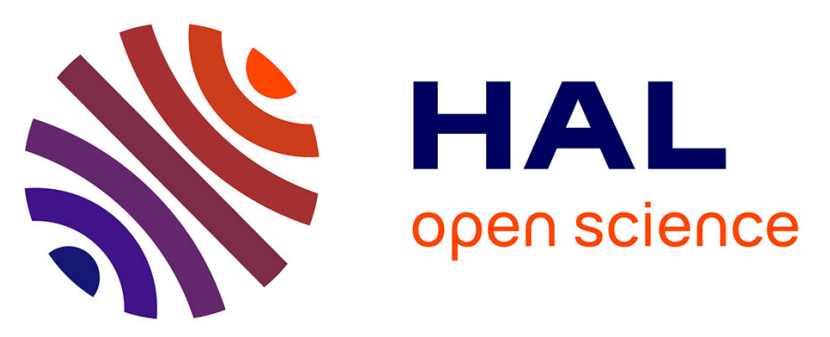

\title{
Long-term ecological observatories needed to understand ecohydrological systems in the Anthropocene: a catchment-scale case study in Brittany, France
}

\author{
Zahra Thomas, Pauline Rousseau-Gueutin, Benjamin W Abbott, Tamara \\ Kolbe, Hugo Le Lay, Jean Marçais, Francois Rouault, Christophe Petton, \\ Pascal Pichelin, Geneviève Le Hennaff, et al.
}

\section{To cite this version:}

Zahra Thomas, Pauline Rousseau-Gueutin, Benjamin W Abbott, Tamara Kolbe, Hugo Le Lay, et al.. Long-term ecological observatories needed to understand ecohydrological systems in the Anthropocene: a catchment-scale case study in Brittany, France. Regional Environmental Change, 2019, 19 (92), pp.363-377. 10.1007/s10113-018-1444-1 . insu-01987256

\section{HAL Id: insu-01987256 \\ https://hal-insu.archives-ouvertes.fr/insu-01987256}

Submitted on 16 May 2020

HAL is a multi-disciplinary open access archive for the deposit and dissemination of scientific research documents, whether they are published or not. The documents may come from teaching and research institutions in France or abroad, or from public or private research centers.
L'archive ouverte pluridisciplinaire HAL, est destinée au dépôt et à la diffusion de documents scientifiques de niveau recherche, publiés ou non, émanant des établissements d'enseignement et de recherche français ou étrangers, des laboratoires publics ou privés. 
1 Long-term ecological observatories needed to understand socioecological systems in the

\section{Anthropocene}

Zahra Thomas ${ }^{1 *}$, Pauline Rousseau-Gueutin ${ }^{2}$, Benjamin W. Abbott ${ }^{3}$, Tamara Kolbe ${ }^{4}$, Hugo Le Lay $^{1}$, Jean Marçais ${ }^{4}$, François Rouault ${ }^{1}$, Christophe Petton ${ }^{4}$, Pascal Pichelin ${ }^{1}$, Geneviève Le Hennaff $^{1}$, Hervé Squividant ${ }^{1}$, Thierry Labasque ${ }^{4}$, Jean-Raynald de Dreuzy ${ }^{4}$, Luc Aquilina ${ }^{4}$, Jacques Baudry ${ }^{5}$, Gilles Pinay ${ }^{6}$

${ }^{1}$ UMR SAS, AGROCAMPUS OUEST INRA, 35000 Rennes, France ;

${ }^{2}$ EHESP Rennes, Sorbonne Paris Cité, Paris, France ;

${ }^{3}$ Brigham Young University, Department of Plant and Wildlife Sciences, Provo, USA;

${ }^{4}$ Géosciences Rennes, UMR 6118 CNRS, Université de Rennes 1, Campus de Beaulieu, 35042

Rennes Cedex, France ;

${ }^{5}$ INRA, UMR 980, BAGAP, F-35000 Rennes, France ;

${ }^{6}$ Irstea Lyon, RiverLy, University of Lyon, Villeurbanne, France

zthomas@agrocampus-ouest.fr ; pauline.rousseau-gueutin@ehesp.fr; benabbott@byu.edu;

tamara.kolbe@ posteo.net ; lelayhugo@gmail.com; jean.marcais@gmail.com; rouault@agrocampus-ouest.fr; christophe.petton@univ-rennes1.fr; pascal.pichelin@agrocampus-ouest.fr; genevieve.lehenaff@rennes.inra.fr;

Herve.Squividant@agrocampus-ouest.fr; thierry.labasque@univ-rennes1.fr; aupepin@univrennes1.fr; luc.aquilina@univ-rennes1.fr; jacques.baudry@rennes.inra.fr; gilles.pinay@irstea.fr

* Corresponding author: Zahra Thomas, UMR SAS, AGROCAMPUS OUEST, 65, Rue de Saint Brieuc, CS84215, 35042 Rennes Cedex, tel: +33 223485878 


\section{Abstract}

Over the last half century, humans have become the dominant force driving many of Earth’s cycles. Intensive agriculture and urbanization have simultaneously increased nutrient loading of pastoral landscapes and decreased the capacity of these ecosystems to retain or remove excess nutrients. Widespread degradation of terrestrial and aquatic ecosystems has triggered the establishment of ecological observatories, including the Zone Atelier Armorique (ZAAr) in western France, a part of the International Long-Term Ecological Research network (ILTER). The ZAAr includes a patchwork of land covers and uses, including primary growth forests, intensively cultivated row crops, and ancient bocage fields surrounded by hedgerows. In addition to traditional ecological research at ZAAr, which integrated pedology, hydrology, geochemistry, and hydrogeology, the last 8 years have seen the development of multi-proxy and multi-scale approaches to address surface and groundwater quality. Here, we present a global analysis of this 8 year dataset, including biodiversity, vegetation, soil water storage, and stream and groundwater chemistry. Our results highlight a clear relationship between land use and surface water quality, while groundwater quality appeared largely unrelated to land use, suggesting strong differences in nitrogen removal rates. We observed differences among dry and wet years in nutrient fluxes, with multi-year memory effects apparent for some parameters. Given such complex interactions, including emergent dynamics and decadal to centennial time lags, we conclude that multidimensional observations such as those supported by the ZAAr and other ILTER sites, are critical to understanding socioecological systems in the Anthropocene. resilience, multi-proxy, multi-scale, heterogeneity

\section{Length of manuscript: 5302 words}

\section{Length of figures: 2400 words (8figs*300words)}

Total : 7702 


\section{Introduction}

At a global scale, human activity has surpassed geological and biological forces in many dimensions (Steffen et al. 2007, 2011; Berkhout 2014). While there is a controversy over the starting date and the purview of the Anthropocene (Crutzen 2002; Monastersky 2015), widespread anthropogenic effects on aquatic ecosystems and biodiversity expanded exponentially in the 20th century (Steffen et al. 2011; Zalasiewicz et al. 2015). This period was marked by accelerated industrialization, technological advances, and significant economic and demographic growth. Industrial fertilizer production and increases in international trade resulted in a step-change in agricultural output in the decades following the Second World War (Rudel et al. 2009). Combined with largescale changes in land management (e.g. field consolidation and soil drainage), agricultural production caused widespread degradation of surface water and groundwater quality (Van Meter et al. 2016; Abbott et al. 2018) . Local and global increase of carbon, nitrogen, and phosphorus cycles have been accompanied by changes in the global water cycle and energy balance (Loaiciga 1996; Huntington 2006) threatening biodiversity and human water and food security (Meybeck 2003; Steffen et al. 2015).

Despite the degree and extent of human activity, quantifying anthropogenic effects in terrestrial and aquatic ecosystems remains challenging due to lack of appropriate baselines, incomplete time series, and approaches that often focus on individual response variables (Alagona et al. 2012; Worrall et al. 2015; Pinay et al. 2018). Additionally, while degradation of ecosystem function and services is proportionally related to human disturbance in some (Howarth 2008) instances, there is growing evidence that ecosystem characteristics strongly modulate resistance to anthropogenic pressures and resilience or recovery trajectory following disturbance (Helton et al. 2018). Because decadal to centennial time lags are often involved in complex interactions in socioecological landscapes (Slavik et al. 2004; Worrall et al. 2015; Abbott et al. 2016; Kolbe et al. 2016), long-term and multidimensional observations are needed for sustainable management in the Anthropocene (Burt et al. 2011). Taking water quality as an example, substantial resources have been invested in assessing the impact of agricultural activities on water quality and creating mitigation and adaptation strategies (Singh and Sekhon 1979; Haag and Kaupenjohann 2001; Rodvang and Simpkins 2001).

In this paper, we perform a global analysis of such research carried out at a long-term ecological research site in western France. Data were collected by hydrologists, soil scientists, landscape ecologists, hydrogeologists, and sociologists, allowing us to explore ecohydrological linkages and transfers between different catchment components and to test how human activity has influenced a complex landscape. We first provide an overview of the site and the scope of observation, followed by an analysis of ecohydrological functioning at multiple spatiotemporal scales.

\section{Zone Atelier Armorique (French LTER)}

In Brittany, France, research on surface and subsurface ecology, hydrology, and biogeochemistry has been carried out since 1993 at an international long-term ecological research (ILTER, (Mirtl et al. 2018; Haase et al. 2018) site named the Zone Atelier Armorique (ZAAr). The ZAAr is one of 14 French environmental observatories (http://www.za-inee.org/fr/reseau), and is also integrated into the European, (www.lter-europe.net) 
and international LTER (https://www.ilternet.edu/) networks. Located in western France (48 $36^{\prime}$ N, $1^{\circ} 32^{\prime}$ W; Fig.1a), the ZAAr was created to conduct interdisciplinary research analysing human activities and their effects on environmental systems including hydrology, ecology, and biodiversity in a socioecological context. The ZAAr tries to promote a multidisciplinary approach to understanding socioecological problems, which do not respect traditional boundaries between disciplines and environments (e.g. terrestrial-aquatic, surface-subsurface). Such networks aim to integrate complexity of environmental systems with the interactions between natural systems and society. Specifically, the ZAAr aims to understand the linked dynamics and co-evolution of human and water systems (Thomas et al. 2016b; Abbott et al. 2017; Marcais et al. 2018). A long-term monitoring strategy was developed in the ZAAr to investigate interactions between agricultural practices, landscape structure (e.g. hedgerows, topography, and river networks), water quality, and catchment hydrology. Variable spatial and temporal characteristics in the ZAAr have provided a high-resolution picture of biogeochemical and hydrological drivers of soil, subsurface, and surface water quality.

Research at the ZAAr has been carried out on a long-term basis in partnership with local landowners and decision makers (e.g. local governments) to develop and quantify effectiveness of adaptation and mitigation strategies for sustaining water quality, biodiversity, and human quality of life. The ZAAr focuses on agricultural and urban landscapes and employs both observational and experimental scientific approaches. The ZAAr is composed of three contrasted landscape units: (i) a landscape intersected by a hedgerow network in the PleineFougères area of $93 \mathrm{~km}^{2}$, (ii) an alluvial plain of the Couesnon river which is a Natura 2000 site, and (iii) an urban area in the city of Rennes. These units have been monitored since 1993, 2006, and 2011, respectively. In this paper, we will focus on the Pleine-Fougères ZAAr site (which we refer to simply as the ZAAr), because it is the site with the longest land-use, ecology, and biodiversity time series (i.e. 25 years), as well as high frequency hydrological data since June of 2009.

\subsection{Land-use history and effects on water quality}

Farming in north-western France started millennia ago, consisting of small cultivated fields interspersed with nut and apple trees (Forman and Baudry 1984). Intensive farming appeared in Brittany after the Second World War, when many agricultural fields were consolidated and many hedgerows were cut down (Thomas and Abbott 2018). The hedgerow network covers the ancient landscape of the Massif Armoricain. Dairy farming is the dominant agricultural system. Cows are mostly fed from maize and grass (rotational and permanent grassland) and imported proteins (soybean). Large farms also grow wheat.

Current land use of the ZAAr is dominated by corn, wheat, and pastureland, which follow topographic and geological gradients in the ZAAr (Thomas et al. 2016a). There is a higher density of hedgerows and more pastures for dairy cows in the southern half of the ZAAr, which is granitic and hilly, while there are larger, open fields in the schist lowlands to the north (Fig. 1b). Deeper, loamy soils of 80 to $85 \mathrm{~cm}$ have developed on the granite bedrock in the south part of the ZAAr and shallower soils of 45 to $70 \mathrm{~cm}$ have developed on the schist bedrock in the northern part (UMR 1069 SAS INRA - AGROCAMPUS OUEST). The difference in elevation between the south and the north of the catchment is about 110m (Fig. 1b). The estimated input of nitrogen, including manure and synthetic fertilizer, is around $164 \mathrm{~kg} \mathrm{~N}$ per ha per year, exceeding agricultural nutrient removal by 30\% (van Grinsven et al. 2012; Poisvert et al. 2016). 
The long legacy of land use and excess nutrients have degraded aquatic ecosystems in this area, including lakes, rivers, groundwater, and estuaries (Ben Maamar et al. 2015; Kolbe et al. 2016; Abbott et al. 2018). Average nitrate concentration increased from $9 \mathrm{mg} \mathrm{L}^{-1}$ in 1976 to $65 \mathrm{mg} \mathrm{L}^{-1}$ in 1989 (Cheverry 1998 ), exceeding numerous regulatory limits (European Nitrate directive 1991), and causing widespread harmful algal blooms along Brittany coasts (Perrot et al. 2014). National and international political actions and legal frameworks were set up to reduce fluvial nutrient loads at European, national, and local scales (PMPOA; Action programs for the nitrate directive; European Nitrate directive; Brittany Pure Water Bretagne Eau Pure - BEP; the governmental plan against green algae). The efficiency of these actions is unclear, with some areas where water quality parameters show improvement, and others areas appearing to remain stable (Bouraoui and Grizzetti 2011; Abbott et al. 2018). For example, nitrate concentration in surface water shows a slight improvement, and to a lesser extent, in shallow groundwater (Aquilina 2012). As elsewhere, recovery trajectories (ecosystem resilience) depends not only on nutrient inputs, but also on retention and removal capacity in different catchment components (i.e. stream, groundwater, wetland, riparian vegetation, hedgerows, etc. (Pinay et al. 2018). Specifically, nitrate retention and removal in a catchment depend on physical and biological conditions in soils, groundwater, and streams, which determine assimilatory uptake and dissimilatory use in denitrification (Thomas and Abbott 2018). Denitrification requires nitrate, an electron donor (e.g. carbon or pyrite), and anoxic conditions that co-occur in areas such as wetlands, aquifers, and hyporheic zones (Gilliam 1994; Vidon and Hill 2004; Trauth et al. 2015). Areas of preferential denitrification change in space and time (McClain et al. 2003), due to variation in hydrological and biological conditions (Moatar et al. 2017), making the assessment of the removal capacity at catchment-scale difficult. The distribution of nutrient sources and sinks is strongly influenced by landscape structure, including hedges, embankments, and ditches (Bernhardt et al. 2003; Hall et al. 2009; Worrall et al. 2012; Schelker et al. 2016), though these relationships do not always hold at small spatial scales (Burt 2005; Abbott et al. 2017). At the catchment scale, hedgerows play an important role in the regulation of floods (Merot 1999), and at the local scale, they can alter water-table depth and nutrient transfer (Caubel-Forget and Grimaldi 2001; Guo et al. 2007; Thomas et al. 2016a).

\section{Methods}

\subsection{Land use and meteorological data}

From 1993 until 2013, land use mapping was carried out annually in the ZAAr. Digital maps were produced from summer aerial photography by geographers at the University of Rennes 2 (COSTEL, UMR LETG). This detailed classification was used to evaluate agricultural practices, in combination with regional accounting (farmers reporting their land use directly as required by law into a geographic information system). These two types of data provided information on how crops were distributed among farms and farm types. Finally, detailed ground surveys have been carried out since 1995 four times a year from the same 300 field margins distributed across areas of the ZAAr with different field margin densities.

Meteorological data were available from the Meteo France weather station located in Louvigné du desert, $37 \mathrm{~km}$ from the outlet of the studied area. A weather station was installed in 2009 inside the ZAAr to record air temperature, humidity, wind speed and direction, global and reflected radiation, and soil temperature at 3 depths 
$(50,100$, and $180 \mathrm{~cm})$ at a 5 minute interval. An automatic rain gauge recorded instantaneous pulses of rainfall with a $0.24 \mathrm{~mm}$ resolution. A manual rain gauge was also installed to verify cumulative rainfall.

\subsection{Hydrological monitoring}

Since 2009, high-frequency monitoring of soil moisture, groundwater, discharge, and water quality has been performed with a particular focus on the role of landscape structures in the variability of nitrogen fluxes in the ZAAr. The time step of our measurements ranged between 10 minutes for groundwater level and discharge, 2 weeks for soil moisture, and monthly for water quality. Seventeen agricultural wells from across the ZAAr were selected for water quality analyses (Fig. 1b) and thirteen piezometers were installed on a highly instrumented hillslope crossed by 3 hedgerows near the boundary of a wetland. Groundwater level was measured for each piezometer using pressure head sensors from OTT (Orpheus mini). Table S1 summarises the characteristics of the groundwater wells and shallower piezometers.

Soil moisture at the instrumented hillslope was measured at 25 locations using a capacitance sensor (Diviner 2000, Sentek) (Paltineanu and Starr 1997; Green et al. 2006). Measurements were performed along a soil profile of $140 \mathrm{~cm}$. Water storage ( $\Delta S_{\text {year }}$ ) was calculated from monthly or bimonthly soil moisture measurements to a depth of $60 \mathrm{~cm}$ for sensors located within and beyond the rooting zone. For each year and each location, the maximum $\left(\theta_{\max }\right)$ and minimum $\left(\theta_{\min }\right)$ values were used to assess water storage $\left(\Delta S_{\text {year }}\right)$ using Equation 2.

$$
\Delta S_{\text {year }}=\int_{0}^{z}\left(\theta_{\max }-\theta_{\min }\right) \cdot d z
$$

Equation 2

Stream discharge and water temperature were monitored for 13 small catchments within the ZAAr, ranging from 2 to $35 \mathrm{~km}^{2}$ (Fig. 1b). Data from one of the 13 catchments and 2 additional catchments were collected from 1996 to 1999 and from 2012 until 2017 (catchments G1, S1 and GS1; Thomas et al 2016). Table S2 summarises the characteristics of the stream water data of these 15 catchments.

Additional discharge and nitrate concentration data were available from the public institution DREAL (Directions Régionales de l'Environnement, de l'Aménagement et du Logement) at two hydrometric stations adjacent to the ZAAr (Le Guyoult and the Couesnon Rivers; Fig. 1b). Maps of weathered layer thickness, aquifer thickness, and bedrock are available through the French geological survey (BRGM), and hydrological and geological information are available through openGIS web map services (WMS; Kolbe et al., 2016).

Monthly to bimonthly stream and groundwater samples were collected from December 2012 to June 2016. Stream water from 6 nested catchment outlets were sampled at each date (Fig. 1b) and 2 additional catchments (G1 and S1) from Thomas et al. (2016) were also integrated in our global analysis. Water samples from surface sampling points and groundwater wells were filtered to $0.45 \mu \mathrm{m}$ through polyethersulfone filters and major anions were measured using ion chromatography as described in (Thomas et al. 2016). Table S2 summarises the frequency of sampling and the list of parameters analysed. 
All the time series analyses (i.e. precipitation, discharge, potential evaporation, groundwater level, water quality, and soil moisture) were calculated for each hydrological year from 1 of September to 31 of August of the next year.

\subsection{Temperature monitoring}

In addition to air temperature measurements collected at the weather station, individual temperature probes were installed to characterise the thermal signature in stream water $\mathrm{T}_{\mathrm{sw}}$, groundwater $\mathrm{T}_{\mathrm{gw}}$, multiple depths of the hyporheic zone $\mathrm{T}_{\text {hypo }}$ ( 3 or 6 depths for each site), and 3 key-locations in the soil along the hillslope: recharge zone; $\mathrm{T}_{\text {soi_rz }}$, for the mid and bottom locations; $\mathrm{T}_{\text {soi_m }}$, and $\mathrm{T}_{\text {soi_b }}$, respectively. Some of the temperature sensors were installed at the beginning of the monitoring period (September 2009), allowing quantification of inter and intra-annual variation as well as long-term trends.

We also deployed fibre optic distributed temperature sensors $\left(\mathrm{T}_{\mathrm{fo}}\right.$; FO-DTS) along a $600 \mathrm{~m}$ reach in one of the nested catchments. Continuous FO-DTS measurements allowed characterization of the location and time of stream-groundwater exchange. Spatial resolution of the FO-DTS was about $0.5 \mathrm{~m}$ with a sampling frequency of 20 minutes from July 2016 to July 2017.

\section{Results}

\subsection{ZAAr land use evolution}

Land use changed substantially from 1993 to 2013 (Fig. S1). In 1993 to 1998, pasture occupied 15-30 \% of the landscape, increasing to 35-45\% in 1999 to 2013, with a maximum of around 60 \% in 2009. Maize and cereal cultures covered 15-25\% of the area from 2000 to 2009, increasing to $40 \%$ in 2010 to 2013. Initially, 15$28 \%$ of the landscape was not used for agricultural practices, decreasing to $\sim 10 \%$ in 2010 . The forested area ( $\sim 10 \%$ of the landscape) was stable over the investigated time period. Wild field margins represented less than $3 \%$ of the ZAAr area initially, decreasing to less than 1\% in 2010. These trends towards less permanent pasture and more cultivated land matched larger regional changes from 2006 to 2014 (Public Sata Source : RPG Ille-etVilaine).

\subsection{Hydrological compartments characterization}

\subsubsection{Soil moisture and groundwater variation under a contrasted climatic context}

Historical data from Meteo-France over a 30 years period revealed substantial variability in precipitation and evapotranspiration (Fig. 2). The hydrological years 1988-1993, 1995-1998, 2001-2006, 2009-2012, and 20142016 were relatively dry with net precipitation (P-PET) lower than $200 \mathrm{~mm}$. 2009-2010 and 2016-2017 were the driest years with negative net precipitation of $-10 \mathrm{~mm}$ and $-137 \mathrm{~mm}$, respectively. The wettest hydrological years were 1998-2000, 2006-2007, and 2013-2014 with net precipitation between 450 and 600 mm (Fig. S2). The cumulative rainfall was lowest in 2009-2010 (736 mm) and highest in 2013-2014 (1180 mm; Fig.2 and Fig. S2). 
Soil moisture measurements at the recharge zone of the hillslope within and beyond the rooting zone were used to calculate water storage ( $\Delta S_{\text {year }}$ ) (Fig. 3). Soil water storage in both zones followed net precipitation except for the beginning of the observed time series. Soil moisture within the rooting zone was systematically drier in 6 of the 8 observed years, independent of other hydrological changes. Water storage was highest beyond the rooting zone in the middle of a meadow far away from the root system of hedgerows.

Groundwater level in the recharge zone (P02 in Fig. 5) was most variable for the 8-year period. 20162017 showed the lowest variability in groundwater level, with only $3 \mathrm{~m}$ of change observed during the hydrological year, contrasted with $8 \mathrm{~m}$ of change in 2012-2013 and 2013-2014, when net precipitation was high (Fig. S3). Annual minimum groundwater level was surprisingly stable across the 8-year time series, varying only $\sim 70 \mathrm{~cm}$. The highest groundwater level observed during the low water period was $\sim 12 \mathrm{~m}$ A.S.L in August 2014 and the lowest was $11.3 \mathrm{~m}$ A.S.L. in early November 2016.

\subsubsection{Stream discharge}

Long-term discharge over 30 years at the Couesnon gauging station showed highest discharge in 20002001, the wettest year of the period of record, and the lowest discharge in 1991-1992 (Fig.2). 2009-2010 was the driest year, but fall and winter precipitation was high, preventing extreme low flows in the late fall. Discharge remained high from September 2013 to September 2016 despite a small decrease in annual rainfall over these years (Fig. 5, Fig. S2). The hydrological year 2016-2017 was extremely dry, surpassing the 2 previous dry years with low cumulative rainfall, high cumulative PET, and extremely low maximum discharge (Fig.2).

\subsection{Biogeochemical reactivity in catchment compartments}

\subsubsection{Spatial analysis of nitrate concentrations}

Mean nitrate concentration in deep groundwater (i.e. 28 to 98m) showed high spatial variability over the ZAAr area (Fig. 4b). No clear relationship between well depth and nitrate concentration was found. The wells located on granite bedrock tended to have nitrate concentration lower than $35 \mathrm{mg} \mathrm{L}^{-1}$ (wells $\mathrm{F} 1$ to $\mathrm{F} 6$ ), the well F16, at the transition between granite and schist, had a very high concentration of nitrate $\left(75 \mathrm{mg} \mathrm{L}^{-1}\right)$, and 5 of the 10 wells in schist bedrock had no nitrate (F7, F9, F10, F11 and F12) but the other half had concentration between 33 and $64 \mathrm{mg} \mathrm{L}^{-1}$ (F8, F13, F14, F15 and F17).

Nitrate concentration measured in the shallow groundwater (i.e. $<10 \mathrm{~m}$ from soil surface (P1 to P13)) showed a gradient between the recharge zone and wetland (Fig. 5a and B). In the recharge zone, high nitrate concentration (40-60 $\mathrm{mg} \mathrm{L}^{-1}$ ) was observed, approximately the same concentration as the deep groundwater (Fig. 5b). Nitrate concentration was highest $\left(\sim 70 \mathrm{mg} \mathrm{L}^{-1}\right)$ at the mid-slope where an artesian upwelling zone occurred (Clement et al. 2003). Nitrate concentration decreased abruptly from 65 to $0 \mathrm{mg} \mathrm{L}^{-1}$ in the wetland.

Figure 4a shows the mean nitrate concentration in stream water measured over the periods indicated in Table S2. Overall, concentration was much less variable in surface waters than in groundwater. For the headwater catchments located in the granitic part of ZAAr, nitrate concentration was lower than $25 \mathrm{mg} \mathrm{L}^{-1}$ (Fig. 4a). Nitrate 
concentration increased with drainage area and intensive agricultural land contribution but the mean value remained below $40 \mathrm{mg} \mathrm{L}^{-1}$ except for the catchments $\mathrm{S} 1$ and BV8, and Couesnon station.

At the catchment scale, there was generally a good agreement between land use type and surface-water exports, with nitrate concentration increasing with intensive row-crop land use (Fig. 4a). These results highlight a direct relationship between land use and nitrate concentration in stream water. However, there was little or no relationship between land use and groundwater nitrate concentration, suggesting that ecosystem removal processes control water quality in this catchment component.

\subsubsection{Temporal analyses of nitrate concentration and sources}

We tested for interannual trends in nitrate concentration using mean nitrate concentration for each year across all sites within each of the different hydrological compartments (i.e. deep groundwater, shallow groundwater, wetland, near stream-groundwater, and stream water). Nitrate concentration was high for deep and shallow groundwater and showed more temporal variability in shallow than in deep groundwater. The concentration in the wetland was very low or below detection through the years. Temporal variability (as indicated by the standard deviation) decreased over the time series, though part of this is likely due to changes in sampling frequency (Fig. 7). Mean annual nitrate concentration and discharge were correlated, though this linkage differed across timescales. At a finer time scale (Fig. 6), stream nitrate concentration varied between groundwater concentration and near stream groundwater. However, starting in the winter of 2014, we observed an increase in nitrate concentration at the beginning of the recharge period and a decrease until the end of recharge period.

Stream discharge over the 29 years period showed high variability, ranging from $2.5 \mathrm{~m}^{3} \mathrm{~s}^{-1}$ to $19 \mathrm{~m}^{3} \mathrm{~s}^{-1}$, but nitrate concentration was quite stable in time, ranging less than a factor of 2 from $32 \mathrm{mg} \mathrm{L}^{-1}$ to $50 \mathrm{mg} \mathrm{L}^{-1}$ (Fig. 6). Seasonal analysis of mean nitrate concentration and discharge showed no correlation except during the winter where dilution is observed as nitrate concentration decreases when discharge increases (Fig. S4).

We used the ratio of nitrate to chloride $\left(\mathrm{NO}_{3}: \mathrm{Cl}\right)$ to identify potential processes controlling nitrate concentration (Fig. 8). Three processes can be identified from the $\mathrm{NO}_{3}$ : $\mathrm{Cl}$ ratio: (i) denitrification is characterized by a $\mathrm{NO}_{3}: \mathrm{Cl}$ ratio less than 1 and low chloride concentration, (ii) agricultural inputs are characterized by a $\mathrm{NO}_{3}: \mathrm{Cl}$ ratio much higher than 1 and low chloride concentration, (iii) and sewage inputs are characterized by a $\mathrm{NO}_{3}: \mathrm{Cl}$ ratio much smaller than 1 and high chloride concentration. Deep wells fell into two groups, with F3, F8, F14, and F15 expressing a high NO3:Cl ratio and low chloride concentration (Fig. 8a), and the other deep wells showing a NO3:Cl ratio $<1$ and low chloride concentration.

In the shallow GW (P1-P11), the $\mathrm{NO}_{3}$ : $\mathrm{Cl}$ ratio as well as the chloride concentration were highly variable and changed over time (Fig. 10b). In the near stream and wetland area $\mathrm{NO}_{3}: \mathrm{Cl}$ ratio was lower than one and chloride concentration was low (Fig. 10c). The stream water ratio (Fig. 8a) varied in time except for the catchment located in the forested zone, which had a very low $\mathrm{NO}_{3}: \mathrm{Cl}$.

\section{Discussion}


Nitrate concentration at the ZAAr seems to be controlled by two main processes: agricultural inputs and denitrification. Wetland and stream $\mathrm{NO}_{3}: \mathrm{Cl}$ ratios suggest that denitrification is the main process controlling nitrate concentration in these hydrological compartments. For the deep groundwater, some wells showed a $\mathrm{NO}_{3}: \mathrm{Cl}$ ratio characteristic of agricultural inputs while others showed a $\mathrm{NO}_{3}: \mathrm{Cl}$ ratio characteristic of denitrification. This agrees with observations that pyrite and anoxic conditions in aquifers can be very localised (Ben Maamar et al. 2015). For the shallow groundwater in the hillslope, there was high temporal and spatial variation in nitrate concentration (Fig. 6). The nitrate signature in piezometers located at the crest to the mid-slope suggests that agricultural inputs are the main source of nitrate to the system. The nitrate signature of the wells at the mid-slope hedgerow suggests that denitrification occurs at this location, probably stimulated by the presence of the hedgerow (Caubel-Forget and Grimaldi 2001; Grimaldi et al. 2012; Thomas and Abbott 2018). This is the case as well for the piezometer P11 which is localised in a more forested area of the catchment and nevertheless has a nitrate concentration of $\sim 40 \mathrm{mg} \mathrm{l}^{-1}$.

These results suggest that for surface-water compartments such as streams, riparian areas, wetlands, and near-surface groundwater are quite vulnerable to nitrate contamination from agricultural activity. On the other hand, deep groundwater was resistant to excess nutrient inputs, with ecosystem characteristics, in this case conditions for denitrification (Kolbe et al. 2016; Abbott et al. 2016; Marcais et al. 2018), determining water chemistry. However, on longer time-scales those favourable conditions for denitrification could change, potentially due to depletion of electron donors or changes in groundwater recharge caused by climate change (Tesoriero et al. 2000; Jasechko et al. 2017). For both surface and groundwater, best management practices such as cover crops, riparian buffers, and hedgerows could increase ecosystem resistance and resilience to excess nutrients, while also enhancing other ecosystem functions and services (Caubel-Forget et al. 2001; Grimaldi et al., 2012; Thomas and Abbott, 2018; Pinay et al. 2018).

As for many complex landscapes, the ZAAr is experiencing multiple changes in pressures and internal structure simultaneously. Variability of nitrate concentration and flux in time was mainly driven by meteorological conditions and associated changes in discharge (Moatar et al. 2017; Thomas et al. 2016a). Spatial variability, on the other hand, depended on landscape structure, including subsurface denitrification capacity, the presence of wetland and hedgerows, and land use. Climate is a second forcing to explain nitrate concentrations in the stream water. Consequently, the overall ecosystem state of this landscape in the future will depend on the interaction between direct human disturbance and climate change.

\subsection{Using long-term studies to promote socio-hydrological research}

Understanding processes at the catchment scale requires multidisciplinary approaches capable of characterizing human actions such as land use, physical characteristics such as geology and hydrology, and ecological processes such as denitrification, succession, and migration (Alvarez-Cabria et al. 2016; Malone et al. 2018). While involving multiple perspectives is laudable and in many cases essential, it also poses several challenges, including:

(i) Identifying processes and parameters of concern in the socioecological domain, which are not easily comparable 
(ii) Learning disciplinary language and perspectives, which often use the same terms or interpret the same findings differently

(iii) Obtaining relevant metrics and measurements to quantify vulnerability, resilience, and adaptation capacities

(iv) Generalizing these metrics and measurements to predict ecosystem functioning in areas with less data or without data

Two characteristics of socio-hydrological systems is that they scale by stream order and connectivity and that they are increasingly dominated by anthropogenic drivers (i.e. direct disturbance and climate change (Meybeck 2003; Helton et al. 2012; Savenije et al. 2014). This is particularly apparent in the ZAAr, where connectivity between surface water and groundwater varies spatially from small headwater subcatchments to large lowland catchments, integrating multiple landscape types and disturbance modes. The contribution of nutrients from each tributary depends on multiple overlapping temporal signals stemming from weather, climate, land use, topography, soil thickness, and geological bedrock properties (Gao et al. 2016; Abbott et al. 2017). Characteristic response times of water or elemental flow depend on the distribution of transit times, which itself depends on system size and properties fixing the balance between vulnerable young water systems and resilient old water systems (Marçais et al. 2015; Abbott et al. 2016; Jasechko et al. 2017).

Planning and decision making for socio-hydrological systems that do not integrate the interactions between multiple scales and dimensions are bound to fail, as they do not consider how upstream and downstream effects in space and time can alter adaptation and mitigation or increase vulnerability. It will likely always be difficult to determine multi-dimensional ecosystem resistance and resilience, but long-term and diverse observations give us the best chance to apply precautionary principles and protect ecosystems in the Anthropocene. A spatial approach can help map vulnerable patches, and repeat sampling can quantify how these patches change in time, allowing identification of both spatial and temporal drivers of ecological functioning (Abbott et al. 2017).

\subsection{How to promote sustainable management}

Landscape management and land-use distribution are both strongly contingent on the past, including cultural, technological, and ecological legacies. In an engineering perspective, achieving sustainable management simply entails controlling human activities so they do not exceed the capacity of natural environments. However, neither collective human behaviour nor ecological dynamics can be handled on engineering principles. Over the past 50 years, changes in agricultural techniques and regional management have significantly increased food production and slowed ecological degradation in many areas, achieving ecological and societal good simultaneously. In the same time period, anthropogenic climate change is increasing environmental systems' variability, potentially undermining the mutually beneficial shifts in management. The current challenge is to throttle human footprint adaptively to match dynamic regional carrying capacities. Multidisciplinary approaches are needed to address both the ecological and social aspects of this formidable challenge. The relationship between pressure from agricultural sources and changes in ecosystems and water quality is inherently difficult because several physical parameters of the environment and human actions are acting in the same direction at the same time. This collinearity complicates identifying causality and reliably establishing best practices. 
In Brittany and other regions of Europe, high nitrate concentration triggered multi-level regulation and reform. Management practices such as field margins, cover crops, and grass buffer strips were implemented. While no single intervention has been a panacea, ecologists from the ZAAr are still finding evidence that many of these measures effectively preserve biodiversity and serve society (Alignier and Baudry 2015; Baudry et al. 2017). The regulatory framework may highlight a single ecosystem dimension (in this case nitrate concentration) but secondary and tertiary costs and benefits must be considered as well (PMPOA 1993 to 2002, Action programs for the nitrate directive, since 1996 , European Nitrate directive, Brittany Pure Water (Bretagne Eau Pure - BEP) from1994 to 2006, The governmental plan against green algae - since 2009). The efficacy of these actions remains uncertain, with some areas and water quality parameters showing improvement, and others appearing to remain stable (Bouraoui and Grizzetti 2011). In the ZAAr it is still difficult to draw firm conclusions about the efficacy of interventions at catchment scales, but it is clear that the positive or null results will only become clear with deliberate and long-term monitoring of holistic socioecological functioning. Collaborative research that involves the community moves us towards the goal of helping each actor of the system to be involved and informed about the risks and profits of each action. 


\section{Acknowledgments}

This research was supported in part by the French National Research Agency (ANR; Project ANR-08STRA-01) and the European Union Inter-national Training Network "Ecohydrological interfaces as critical hotspots for transformations of ecosystem exchange fluxes and biogeochemical cycling” (ITN -INTERFACES FP7-PEOPLE-2013- No. 607150). This research was also supported by the French EC2CO grant “Caractérisation hydrologique et biogéochimique de la denitrification dans les paysages”. The study was supported by the LTSER "Zone Atelier Armorique”. We thank all the farmers of the ZAAr who kindly accepted the installation of the experiments in their fields. We also thank all the staff of the ILTER Zone Atelier Armorique, especially the technicians of OSUR-INRA-AGROCAMPUS who helped in sampling and laboratory analysis.

Abbott BW, Baranov V, Mendoza-Lera C, Nikolakopoulou M, Harjung A, Kolbe T, Balasubramanian MN, Vaessen TN, Ciocca F, Campeau A, Wallin MB, Romeijn P, Antonelli M, Gonçalves J, Datry T, Laverman AM, de Dreuzy J-R, Hannah DM, Krause S, Oldham C, Pinay G (2016) Using multi-tracer inference to move beyond single-catchment ecohydrology Earth-Science Reviews 160:19-42 doi:10.1016/j.earscirev.2016.06.014

Abbott BW, Gruau G, Zarnetske JP, Moatar F, Barbe L, Thomas Z, Fovet O, Kolbe T, Gu S, Pierson-Wickmann AC, Davy P, Pinay G (2017) Unexpected spatial stability of water chemistry in headwater stream networks Ecology letters 21:296-308 doi:10.1111/ele.12897

Abbott BW, Moatar F, Gauthier O, Fovet O, Antoine V, Ragueneau O (2018) Trends and seasonality of river nutrients in agricultural catchments: 18years of weekly citizen science in France The Science of the total environment 624:845-858 doi:10.1016/j.scitotenv.2017.12.176

Alagona P, Sandlos J, Wiersma Y (2012) Past imperfect: using historical ecology and baseline data for conservation and restoration projects in North America Environ Philos 9:49-70 doi:doi: 10.5840/envirophil2012914

Alvarez-Cabria M, Barquin J, Penas FJ (2016) Modelling the spatial and seasonal variability of water quality for entire river networks: Relationships with natural and anthropogenic factors The Science of the total environment 545-546:152-162 doi:10.1016/j.scitotenv.2015.12.109 
Aquilina L, Vergnaud-Ayraud, V., Labasque, T., Bour, O., Molenat, J., Ruiz, L., de Montety, V., De Ridder, J., Roques, C., Longuevergne, L. (2012) Nitrate dynamics in agricultural catchments deduced from groundwater dating and long-term nitrate monitoring in surface- and groundwaters Science of the Total Environment 435:167-178 doi:10.1016/j.scitotenv.2012.06.028

Ben Maamar S, Aquilina L, Quaiser A, Pauwels H, Michon-Coudouel S, Vergnaud-Ayraud V, Labasque T, Roques C, Abbott BW, Dufresne A (2015) Groundwater Isolation Governs Chemistry and Microbial Community Structure along Hydrologic Flowpaths Frontiers in microbiology 6:1457 doi:10.3389/fmicb.2015.01457

Bouraoui F, Grizzetti B (2011) Long term change of nutrient concentrations of rivers discharging in European seas The Science of the total environment 409:4899-4916 doi:10.1016/j.scitotenv.2011.08.015

Burt TP, Howden NJK, Worrall F, McDonnell JJ (2011) On the value of long-term, lowfrequency water quality sampling: avoiding throwing the baby out with the bathwater Hydrological Processes 25:828-830 doi:10.1002/hyp.7961

Burt TP, Pinay, G, (2005) Linking hydrology and biogeochemistry in complex landscapes. Progress in Physical Geography 29:297-316

Caubel-Forget V, Grimaldi C, Rouault, F., (2001) Contrasted dynamics of nitrate and chloride in groundwater submitted to the influence of a hedge C R Acad Sci Paris 332:107-113

Cheverry C (1998 ) Agriculture intensive et qualité des eaux. Editions Quae. INRA,

Forman RTT, Baudry J (1984) Hedgerows and hedgerow networks in landscape ecology Environmental management 8:495-510 doi:10.1007/bf01871575

Gao HK, Hrachowitz M, Sriwongsitanon N, Fenicia F, Gharari S, Savenije HHG (2016) Accounting for the influence of vegetation and landscape improves model transferability in a tropical savannah region Water Resources Research 52:7999-8022 doi:10.1002/2016wr019574

Grimaldi C, Fossey M, Thomas Z, Fauvel Y, Merot P (2012) Nitrate attenuation in soil and shallow groundwater under a bottomland hedgerow in a European farming landscape Hydrological Processes 26:3570-3578 doi:10.1002/hyp.8441

Guo ZL, Zhong C, Cai CF, Ding SW, Wang ZM (2007) Nitrogen competition in contour hedgerow systems in subtropical China Nutrient Cycling in Agroecosystems 81:71-83 doi:10.1007/s10705-007-9153-z

Haase P, Tonkin JD, Stoll S, Burkhard B, Frenzel M, Geijzendorffer IR, Hauser C, Klotz S, Kuhn I, McDowell WH, Mirtl M, Muller F, Musche M, Penner J, Zacharias S, 
Schmeller DS (2018) The next generation of site-based long-term ecological monitoring: Linking essential biodiversity variables and ecosystem integrity The Science of the total environment

613-614:1376-1384 doi:10.1016/j.scitotenv.2017.08.111

Helton AM, Hall RO, Bertuzzo E (2018) How network structure can affect nitrogen removal by streams Freshwater Biology 63:128-140 doi:10.1111/fwb.12990

Helton AM, Poole GC, Payn RA, Izurieta C, Stanford JA (2012) Scaling flow path processes to fluvial landscapes: An integrated field and model assessment of temperature and dissolved oxygen dynamics in a river-floodplain-aquifer system Journal of Geophysical Research: Biogeosciences 117:n/a-n/a doi:10.1029/2012jg002025

Howarth RW (2008) Coastal nitrogen pollution: A review of sources and trends globally and regionally Harmful Algae 8:14-20 doi:10.1016/j.hal.2008.08.015

Huntington TG (2006) Evidence for intensification of the global water cycle: Review and synthesis Journal of Hydrology 319:83-95 doi:10.1016/j.jhydrol.2005.07.003

Jasechko S, Debra Perrone, Befus KM, M. Bayani Cardenas, Grant Ferguson, Tom Gleeson, Elco Luijendijk, McDonnell JJ, Richard G. Taylor, Wada Y, Kirchner JW (2017) Global aquifers dominated by fossil groundwaters but wells vulnerable to modern contamination Nature Geoscience doi:DOI: 10.1038/NGEO2943

Kolbe T, Marçais J, Thomas Z, Abbott BW, de Dreuzy J-R, Rousseau-Gueutin P, Aquilina L, Labasque T, Pinay G (2016) Coupling 3D groundwater modeling with CFC-based age dating to classify local groundwater circulation in an unconfined crystalline aquifer Journal of Hydrology 543, Part A:31-46 doi:doi.org/10.1016/j.jhydrol.2016.05.020

Loaiciga HA, Valdes, J. B. , Vogel, R., Garvey, J., Schwarz, H. (1996) Global warming and the hydrologic cycle Journal of Hydrology 174:83-127

Malone ET, Abbott BW, Klaar MJ, Kidd C, Sebilo M, Milner AM, Pinay G (2018) Decline in Ecosystem $813 \mathrm{C}$ and Mid-Successional Nitrogen Loss in a Two-Century Postglacial Chronosequence Ecosystems doi:10.1007/s10021-018-0245-1

Marçais J, de Dreuzy JR, Ginn TR, Rousseau-Gueutin P, Leray S (2015) Inferring transit time distributions from atmospheric tracer data: Assessment of the predictive capacities of Lumped Parameter Models on a 3D crystalline aquifer model Journal of Hydrology 525:619-631 doi:10.1016/j.jhydrol.2015.03.055

Marcais J, Gauvain A, Labasque T, Abbott BW, Pinay G, Aquilina L, Chabaux F, Viville D, de Dreuzy JR (2018) Dating groundwater with dissolved silica and CFC concentrations in 
crystalline aquifers The Science of the total environment 636:260-272 doi:10.1016/j.scitotenv.2018.04.196

Merot P (1999) The influence of hedgerow systems on the hydrology of agricultural catchments in a temperate climate. Agronomie 19:655-669

Meybeck M (2003) Global analysis of river systems: from Earth system controls to Anthropocene syndromes Philosophical transactions of the Royal Society of London Series B, Biological sciences 358:1935-1955 doi:10.1098/rstb.2003.1379

Mirtl M, E TB, Djukic I, Forsius M, Haubold H, Hugo W, Jourdan J, Lindenmayer D, McDowell WH, Muraoka H, Orenstein DE, Pauw JC, Peterseil J, Shibata H, Wohner C, Yu X, Haase P (2018) Genesis, goals and achievements of Long-Term Ecological Research at the global scale: A critical review of ILTER and future directions The Science of the total environment 626:1439-1462 doi:10.1016/j.scitotenv.2017.12.001

Moatar F, Abbott BW, Minaudo C, Curie F, Pinay G (2017) Elemental properties, hydrology, and biology interact to shape concentration-discharge curves for carbon, nutrients, sediment, andmajor ions water Resources Research doi:10.1002/2016WR019635

Perrot T, Rossi N, Ménesguen A, Dumas F (2014) Modelling green macroalgal blooms on the coasts of Brittany, France to enhance water quality management Journal of Marine Systems 132:38-53 doi:10.1016/j.jmarsys.2013.12.010

Pinay G, Bernal S, Abbott BW, Lupon A, Marti E, Sabater F, Krause S (2018) Riparian Corridors: A New Conceptual Framework for Assessing Nitrogen Buffering Across Biomes Frontiers in Environmental Science 6 doi:10.3389/fenvs.2018.00047

Poisvert C, Curie F, Moatar F (2016) Annual agricultural N surplus in France over a 70-year period Nutrient Cycling in Agroecosystems 107:63-78 doi:10.1007/s10705-016-9814-X

Rudel TK, Schneider L, Uriarte M, Turner BL, 2nd, DeFries R, Lawrence D, Geoghegan J, Hecht S, Ickowitz A, Lambin EF, Birkenholtz T, Baptista S, Grau R (2009) Agricultural intensification and changes in cultivated areas, 1970-2005 Proceedings of the National Academy of Sciences of the United States of America 106:20675-20680 doi:10.1073/pnas.0812540106

Savenije HHG, Hoekstra AY, van der Zaag P (2014) Evolving water science in the Anthropocene Hydrology and Earth System Sciences 18:319-332 doi:10.5194/hess-18319-2014

Steffen W, Richardson K, Rockstrom J, Cornell SE, Fetzer I, Bennett EM, Biggs R, Carpenter SR, de Vries W, de Wit CA, Folke C, Gerten D, Heinke J, Mace GM, Persson LM, Ramanathan V, Reyers B, Sorlin S (2015) Sustainability. Planetary boundaries: guiding 
human development on a changing planet Science 347:1259855 doi:10.1126/science.1259855

Tesoriero AJ, Liebscher H, Cox SE (2000) Mechanism and rate of denitrification in an agricultural watershed: Electron and mass balance along groundwater flow paths Water Resources Research 36:1545-1559 doi:10.1029/2000wr900035

Thomas Z, Abbott B (2018) Hedgerows reduce nitrate flux at hillslope and catchment scales via root uptake and secondary effects Journal of contaminant hydrology July 5, 2018 doi:https://doi.org/10.1016/j.jconhyd.2018.07.002.

Thomas Z, Abbott B, Troccaz O, Baudry J, Pinay G (2016) Proximate and ultimate controls on carbon and nutrient dynamics of small agricultural catchments Biogeosciences 13:18631875 doi:10.5194/bg-13-1863-2016

Thomas Z, Rousseau-Gueutin P, Kolbe T, Abbott BW, Marçais J, Peiffer S, Frei S, Bishop K, Pichelin P, Pinay G, de Dreuzy JR (2016) Constitution of a catchment virtual observatory for sharing flow and transport models outputs Journal of Hydrology 543, Part A:59-66 doi:doi.org/10.1016/j.jhydrol.2016.04.067

van Grinsven HJM, ten Berge HFM, Dalgaard T, Fraters B, Durand P, Hart A, Hofman G, Jacobsen BH, Lalor STJ, Lesschen JP, Osterburg B, Richards KG, Techen AK, Vertès F, Webb J, Willems WJ (2012) Management, regulation and environmental impacts of nitrogen fertilization in northwestern Europe under the Nitrates Directive; a benchmark study Biogeosciences 9:5143-5160 doi:10.5194/bg-9-5143-2012

Van Meter KJ, Basu NB, Veenstra JJ, Burras CL (2016) The nitrogen legacy: emerging evidence of nitrogen accumulation in anthropogenic landscapes Environmental Research Letters 11:035014 doi:10.1088/1748-9326/11/3/035014

Worrall F, Howden NJK, Burt TP (2015) Evidence for nitrogen accumulation: the total nitrogen budget of the terrestrial biosphere of a lowland agricultural catchment Biogeochemistry 123:411-428 doi:10.1007/s10533-015-0074-7

\section{Figure caption}

Fig. 1 The Location of the Zone Atelier Armorique (ZAAr), an international long-term ecological research site in north-western France (a); ZAAr boundaries, topography, stream network, and location of sampling points (wells and outlets), as well as the location of the highly monitored hillslope (b). Hedgerows density is highest in the hilly southern half of the ZAAr while open fields are dominant in the schist plateau 
Fig. 2 Daily discharge, precipitation (P), and potential evapotranspiration (PET) measured or modeled for the past 30 years. Discharge until 2012 is from the hydrometric station of the Couesnon River (Fig. 1), which is adjacent to the ZAAr, and discharge from 2012 to 2017 (red line) was obtained by transposing the discharge measured at the outlet of the BV6 subcatchment (Fig. 1). Net precipitation was calculated starting in 1993, when PET data became available. Positive and negative values of P-PET (net precipitation) were separated to highlight times of water excess and deficit. Over the period of record, mean annual precipitation $(\bar{P})$ is $914 \mathrm{~mm}$ and mean annual PET is $687 \mathrm{~mm}$

Fig. 3 Water storage $\left(\Delta S_{\text {year }}\right)$ evolution over 8 years since 2009. Water storage calculated for each hydrological year from mean soil moisture measurements along $60 \mathrm{~cm}$ soil profiles in the highly monitored hillslope within (In) and beyond (Out) the rooting zone of hedgerows (Fig. 1). $\mathrm{P}$ is the annual precipitation and P-PET is net precipitation

Fig. 4 Spatial variability of nitrate concentration in stream water (a) and groundwater (b). Each point is the mean value of the time series (see Table S1 and Table S2)

Fig. 5 Nitrate concentration in shallow groundwater along the highly monitored hillslope (P1-P10), in the forested bottomland (P11), in the wetland (P12-P13), and in the stream (a). Mean nitrate concentration ( \pm SD) among points and through time along the hillslope (b). Vertical black lines indicate piezometers position and depth. Discontinuous and continuous blue lines indicate maximum (GWL max) and minimum groundwater (GWL min) level, respectively. The black continuous line shows the soil surface

Fig. 6 Nitrate concentration variation since 2012 in the main hydrological compartments, i.e. streams, deep groundwater (deep GW), shallow groundwater (shallow GW), wetland, and near-stream groundwater (NS-GW)

Fig. 7 Annual mean and standard deviation of stream water nitrate concentration (red line) and discharge (black line) over the past 29 years. The number of nitrate samples per year was about 4 at the beginning of the sampling period, it was about 24 samples per year since 2001-2002

Fig. 8 Relationship between nitrate:chloride ratio and chloride for hydrological compartments: deep groundwater (a), shallow groundwater (b), wetland (c), and streams (d) 
